\title{
Tetraiodobenzimidazoles are potent inhibitors of protein kinase CK2
}

\author{
Alessandra Gianoncelli ${ }^{a}$, Giorgio Cozza ${ }^{a}$, Andrzej Orzeszko ${ }^{b}$, Flavio Meggio ${ }^{a}$, Zygmunt Kazimierczuk ${ }^{c, *}$, \\ Lorenzo A. Pinna ${ }^{\mathrm{a}, *}$ \\ a Department of Biological Chemistry and CNR Institute of Neurosciences, University of Padova, viale G. Colombo 3, 35-121 Padova, Italy \\ ${ }^{\mathrm{b}}$ Military University of Technology, Kaliskiego St. 2, 00-908 Warsaw, Poland \\ ${ }^{\mathrm{c}}$ Laboratory of Experimental Pharmacology, Polish Academy of Sciences Medical Research Center, Pawinskiego St. 5, 02-106 Warsaw, Poland
}

\section{A R T I C L E I N F O}

Article history:

Received 14 April 2009

Revised 20 July 2009

Accepted 21 August 2009

Available online 27 August 2009

\section{Keywords:}

Tetraiodobenzimidazoles

Tetrabromobenzimidazoles

CK2 inhibitors

Molecular modeling

\begin{abstract}
A B S T R A C T
A series of novel iodinated benzimidazoles have been prepared by iodination of respective benzimidazole with iodine and periodic acid in sulfuric acid solution. Additionally several 2-substituted- and $\mathrm{N}$-1-carboxymethyl-substituted derivatives of 4,5,6,7-tetraiodobenzimidazole (TIBI) were obtained. For sake of comparison, some new 4,5,6,7-tetrabromobenzimidazoles were also synthesized. The ability of the new compounds to inhibit protein kinase CK2 has been evaluated. The results show that 4,5,6,7-tetraiodobenzimidazoles are more powerful inhibitors of CK2 than their tetrabrominated analogs. Molecular modeling supports the experimental data showing that tetraiodobenzimidazole moiety fills better the binding pocket than respective tetrabromo and tetrachlorocompounds. To note that 4,5,6,7-tetraiodobenzimidazole (TIBI) is one of the most efficient CK2 inhibitors $\left(K_{\mathrm{i}}=23 \mathrm{nM}\right)$ described to date.
\end{abstract}

(C) 2009 Elsevier Ltd. All rights reserved.

\section{Introduction}

The crucial role of protein kinases in nearly all cellular processes and the growing list of kinases whose dysregulation underlies pathological conditions (www.cellsignal.com/reference/kinase_dis ease.html) highlight the importance of kinases as drug targets. ${ }^{1,2}$ Protein kinases have been actually implicated not only in oncology but also in a number of non-oncology indications including central nervous system disorders, autoimmune disease, post-transplant immunosuppression, osteoporosis, and several metabolic disorders like diabetes. Of special interest, among the large family of protein kinases, appears the regulation of kinases implicated in fundamental processes of cell life like proliferation, survival and apoptosis owing to the crucial commitment with the development and progression of cancer. The search of small molecules capable of downregulating kinase activity was primarily addressed toward the nucleotide pocket of the kinase ${ }^{3}$ exploiting structural differences in this region for molecular recognition. ${ }^{4}$ However, due to the high conservation of the ATP-binding site, development of absolutely specific ATP-competitive inhibitors is hard to attain and the possibility to develop allosteric inhibitors is being explored. ${ }^{4}$

Protein kinase CK2, formerly known as casein kinase-2 or II, is a multifunctional serine/threonine protein kinase that specifically phosphorylates residues located in acidic sequences of more than 300 substrates most of which are phosphorylated also in vivo. ${ }^{5}$ It

\footnotetext{
* Corresponding authors. Tel./fax: +48 228221848.

E-mail addresses: ZKazimierczuk@gmail.com (Z. Kazimierczuk), lorenzo.pinna@ unipd.it (L.A. Pinna).
}

is ubiquitously distributed, constitutively active and participates in a wide variety of cellular processes including gene expression, cell differentiation and proliferation and its activity has been associated with a number of pathologies including inflammation, infection, and tumorigenesis. ${ }^{6-10}$ CK2 overexpression has been invariably observed in transformed tissues and it appears to represent an unfavorable prognostic marker in some types of cancer (e.g., prostate and lung carcinomas and in acute myeloid leukemia). ${ }^{11,12}$ The nucleotide pocket of CK2, which can utilize both ATP and GTP as phosphate donors, displays unique features for being smaller than it is in most other kinases due to the presence of some unique bulky residues hampering the entrance of large molecules like staurosporine, a very powerful, highly promiscuous inhibitor of most protein kinases but weakly effective on CK2. ${ }^{13,14}$ By contrast, smaller molecules which are not retained in the hydrophobic pocket of most kinases are firmly entrapped in that of CK2, resulting in efficient inhibition. The molecular structure of CK2 in mammals invariably consists of a heterotetrameric holoenzyme composed of two catalytic ( $\alpha$ and/or $\alpha^{\prime}$ ) and two regulatory ( $\beta$ ) subunits although emerging evidence would indicate specific roles also for the isolated subunits under certain circumstances. ${ }^{15}$ Searching for CK2 inhibitors, just in the late 1980 s polyhalogenated benzimidazoles were found to represent a valuable scaffold to effectively compete with ATP binding ${ }^{16}$ and 4,5,6,7-tetrabromobenzotriazole (TBB) was later demonstrated to be one of the most powerful and selective cell permeable inhibitors of CK2. ${ }^{17,18}$ The presence of four bromine atoms on the benzene ring of TBB is critical to fill the CK2 hydrophobic pocket adjacent to the ATP-binding site and to assure optimal apolar interactions with 
some bulky side chains, in particular those of Val66 and Ile174. ${ }^{13,14}$ A direct correlation was also recently established for TBB derivatives between the $\log K_{\mathrm{i}}$ and the variation in the accessible surface area upon binding on CK2. ${ }^{13}$ From this point of view, it was known since longtime that the reduction of the number of bromine atoms or their replacement by less bulky halogens like chlorine and fluorine severely impairs the inhibitory efficiency. ${ }^{16,19}$ However, the replacement of all four bromine atoms of the benzoimidazole or benzotriazole moiety by bulkier iodines was hard to attain and iodo-bromo or iodo-chloro benzimidazoles were unknown. Recently, structurally related tetraiodinated-isoindole derivatives were synthesized and found to inhibit protein kinase CK2 in an ATP-competitive manner with $\mathrm{IC}_{50}$ values ranging between 0.15 and $1.5 \mu \mathrm{M} .^{20}$ The highest efficiency documented in the literature for a CK2 inhibitor belongs to a class of pyrazolo-triazine derivatives reported to affect CK2 with $K_{\mathrm{i}}$ values in the nanomolar and subnanomolar range. ${ }^{21,22}$ Regrettably, however, the experimental conditions for these assays were not detailed; this hampers reliable comparison with other inhibitors. In this paper the synthesis of a number of tetraiodinatedbenzimidazoles is described for the first time together with a structure-activity analysis in comparison with the corresponding tetrabrominated derivatives. In most cases the replacement of bromines by iodines increases the potency of the inhibitor reaching with some derivatives $\mathrm{IC}_{50}$ values in the low nanomolar range.

\section{Results and discussion}

\subsection{Chemical syntheses}

In this study, we made an effort to use an iodine-periodic acid system to obtain three series of iodinated heterocyclic compounds, namely iodinated benzimidazoles, benzotriazoles, and indazoles. We succeeded only in the case of benzimidazoles, while the other heterocycles tested, that is, benzotriazoles and indazoles, decomposed under the reaction conditions. The series of variously substituted benzimidazoles 1-13 that are commercially available or were obtained according to the previously described methods (e.g., see ${ }^{23-28}$ ) were used for the synthesis of the respective tetraiodinated derivatives 1a-13a using, with minor modifications, the procedure described for aromatic compounds ${ }^{29}$ (Scheme 1).
Of the obtained tetraiodinatedbenzimidazoles, 2-bromo-4,5, 6,7-tetraiodobenzimidazole (13a) was found particularly useful for further modifications. This compound was converted to 2-mercaptoderivative $\mathbf{1 5}$ in the reaction with thiourea, whereas substitution of its bromine atom with ethanoloamine provided 2ethanoloamino-4,5,6,7-tetraiodobenzimidazole (14), and heating of the compound with sodium acetate in acetic acid yielded the 2-oxoderivative (17) The sulfur atom in $\mathbf{1 5}$ can be easily alkylated by halogenated compounds; for example, we used bromoacetic acid to obtain the respective 2-carboxymethylthioderivative $\mathbf{1 6}$ (Scheme 2).

The ethyl esters of 1-carboxymethyl-substituted tetrahalogenated benzimidazoles (18 and 19) were obtained from 4,5,6,7-tetrabromo- (TBI) and 4,5,6,7-tetraiodobenzimidazole 1a (TIBI) in the reaction with ethyl bromoacetate, using potassium carbonate as base catalyst. The esters were then subject to further modifications, such as alkaline hydrolysis-to provide the respective carboxylic acids 20 and 21. Acetamido derivatives of 4,5,6,7tetrahalogeneobenzimidazoles $\mathbf{2 2}$ and $\mathbf{2 3}$ were obtained by two synthetic procedures: (a) by alkylation of the respective benzimidazole with iodoacetamide, or (b) by amidation with methanolic ammonia. A nucleophilic substitution of above mentioned esters by methylamine or hydrazine yielded the respective $N$-methylamides $\mathbf{2 4}$ and $\mathbf{2 5}$ or hydrazides, $\mathbf{2 6}$ and $\mathbf{2 7}$ (Scheme 3).

\subsection{Biological activity}

Table 1 shows the inhibitory potency of all new derivatives toward protein kinase CK2. Whenever applicable, $K_{\mathrm{i}}$ values of new iodinated inhibitors are reported in comparison with the analogous brominated compounds either newly synthesized and tested here or drawn from the literature. As a main outcome of these determinations we observed firstly that the iodinated inhibitors behave in general more efficiently than the corresponding brominated ones with $K_{\mathrm{i}}$ values for CK2 which, in some cases, reach the low nanomolar range. In particular, the inhibition constants of tetraiodinated compounds 1a, 7a, 9a, and $\mathbf{1 4}(23,24,19$, and $27 \mathrm{nM}$, respectively) are among the lowest values ever reported in literature for CK2 inhibitors. Also these compounds, as it was previously found with similar polyhalogenated derivatives, ${ }^{28}$ behave as competitive inhibitors with respect to the phosphodonor nucleotide,<smiles>[X]c1nc2c([X])c([Y4])c([Y4])c([Y4])c2[nH]1</smiles><smiles>[Y4]c1nc2c([Y13])c([Y14])c([Y13])c([Y4])c2[nH]1</smiles>

1-13

$1 \mathbf{a}-13 a$

$\begin{array}{cccccc} & \mathrm{X}_{1} & \mathrm{X}_{2} & \mathrm{X}_{3} & \mathrm{X}_{4} & \mathrm{X}_{5} \\ \mathbf{1} & \mathrm{H} & \mathrm{H} & \mathrm{H} & \mathrm{H} & \mathrm{H} \\ \mathbf{2} & \mathrm{H} & \mathrm{H} & \mathrm{H} & \mathrm{Cl} & \mathrm{H} \\ \mathbf{3} & \mathrm{H} & \mathrm{H} & \mathrm{H} & \mathrm{Br} & \mathrm{H} \\ \mathbf{4} & \mathrm{H} & \mathrm{H} & \mathrm{Cl} & \mathrm{Cl} & \mathrm{H} \\ \mathbf{5} & \mathrm{H} & \mathrm{H} & \mathrm{Cl} & \mathrm{H} & \mathrm{Cl} \\ \mathbf{6} & \mathrm{H} & \mathrm{H} & \mathrm{Br} & \mathrm{H} & \mathrm{Br} \\ \mathbf{7} & \mathrm{CH}_{3} & \mathrm{H} & \mathrm{H} & \mathrm{H} & \mathrm{H} \\ \mathbf{8} & \mathrm{CH}_{3} & \mathrm{H} & \mathrm{Cl} & \mathrm{Cl} & \mathrm{H} \\ \mathbf{9} & \mathrm{C}_{2} \mathrm{H}_{5} & \mathrm{H} & \mathrm{H} & \mathrm{H} & \mathrm{H} \\ \mathbf{1 0} & \mathrm{CF}_{3} & \mathrm{H} & \mathrm{H} & \mathrm{H} & \mathrm{H} \\ \mathbf{1 1} & \mathrm{C}_{2} \mathrm{~F}_{5} & \mathrm{H} & \mathrm{H} & \mathrm{H} & \mathrm{H} \\ \mathbf{1 2} & \mathrm{Cl} & \mathrm{H} & \mathrm{H} & \mathrm{H} & \mathrm{H} \\ \mathbf{1 3} & \mathrm{Br} & \mathrm{H} & \mathrm{H} & \mathrm{H} & \mathrm{H}\end{array}$

$\begin{array}{cccccc} & \mathrm{X}_{1} & \mathrm{X}_{2}{ }^{\prime} & \mathrm{X}_{3}{ }^{\prime} & \mathrm{X}_{4}{ }^{\prime} & \mathrm{X}_{5}{ }^{\prime} \\ \mathbf{1 a} & \mathrm{H} & \mathrm{I} & \mathrm{I} & \mathrm{I} & \mathrm{I} \\ \mathbf{2 a} & \mathrm{H} & \mathrm{I} & \mathrm{I} & \mathrm{Cl} & \mathrm{I} \\ \mathbf{3 a} & \mathrm{H} & \mathrm{I} & \mathrm{I} & \mathrm{Br} & \mathrm{I} \\ \mathbf{4 a} & \mathrm{H} & \mathrm{I} & \mathrm{Cl} & \mathrm{Cl} & \mathrm{I} \\ \mathbf{5 a} & \mathrm{H} & \mathrm{I} & \mathrm{Cl} & \mathrm{I} & \mathrm{Cl} \\ \mathbf{6 a} & \mathrm{H} & \mathrm{I} & \mathrm{Br} & \mathrm{I} & \mathrm{Br} \\ \mathbf{7 a} & \mathrm{CH}_{3} & \mathrm{I} & \mathrm{I} & \mathrm{I} & \mathrm{I} \\ \mathbf{8 a} & \mathrm{CH}_{3} & \mathrm{I} & \mathrm{Cl} & \mathrm{Cl} & \mathrm{I} \\ \mathbf{9 a} & \mathrm{C}_{2} \mathrm{H}_{5} & \mathrm{I} & \mathrm{I} & \mathrm{I} & \mathrm{I} \\ \mathbf{1 0 a} & \mathrm{CF}_{3} & \mathrm{I} & \mathrm{I} & \mathrm{I} & \mathrm{I} \\ \mathbf{1 1 a} & \mathrm{C}_{2} \mathrm{~F}_{5} & \mathrm{I} & \mathrm{I} & \mathrm{I} & \mathrm{I} \\ \mathbf{1 2 a} & \mathrm{Cl}_{1} & \mathrm{I} & \mathrm{I} & \mathrm{I} & \mathrm{I} \\ \mathbf{1 3 a} & \mathrm{Br} & \mathrm{I} & \mathrm{I} & \mathrm{I} & \mathrm{I}\end{array}$

Scheme 1. Reagents and conditions: (a) $\mathrm{I}_{2}, \mathrm{H}_{5} \mathrm{IO}_{6}, \mathrm{H}_{2} \mathrm{SO}_{4}, 3 \mathrm{~h}, 5-60^{\circ} \mathrm{C}$. 


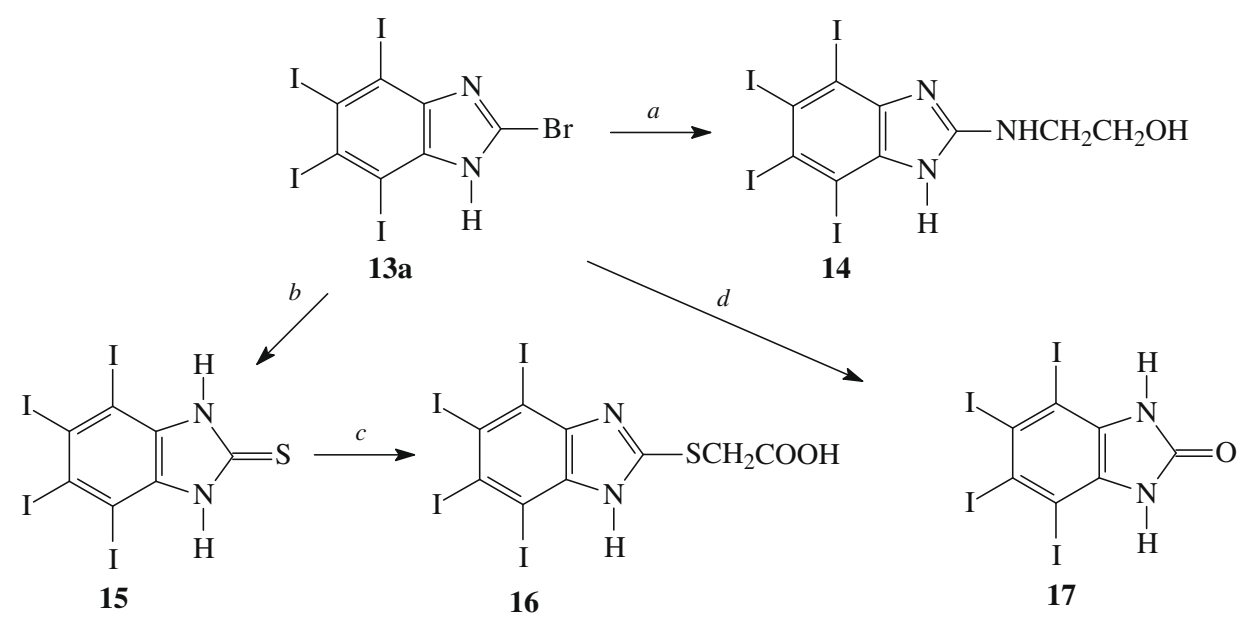

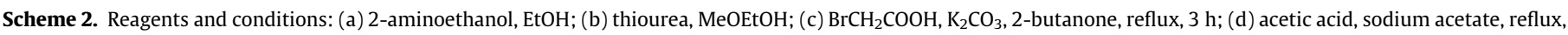
$20 \mathrm{~h}$.<smiles>[X]c1c([X])c([X])c2[nH]cnc2c1[X]</smiles>

TBBz $\mathrm{X}=\mathrm{Br}$ 1a $X=I$<smiles>[X]c1c([X])c([X])c2c(ncn2CC(N)=O)c1[X]</smiles>

$$
\begin{aligned}
& 22 \quad X=B r \\
& \text { 23 X }=\mathrm{I}
\end{aligned}
$$<smiles>CC(C)C</smiles>

$18=B r$
$19 X=I$<smiles>[X]c1c([X])c([X])c2c(ncn2CC(=O)NC)c1[X]</smiles>

$$
24 \mathrm{X}=\mathrm{Br}
$$

$25 \mathrm{X}=\mathrm{I}$<smiles>[X]c1c([X])c([X])c2c(ncn2CC(=O)O)c1[X]</smiles>

$20 \begin{array}{ll}X & =B r \\ 21 & X\end{array}$

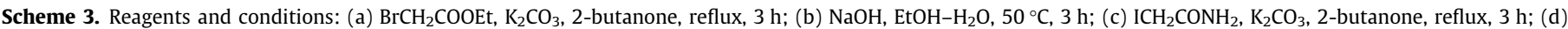
$\mathrm{H}_{2} \mathrm{NCH}_{3}$, EtOH, rt, 2d; (e) $\mathrm{H}_{2} \mathrm{NNH}_{2} \cdot \mathrm{H}_{2} \mathrm{O}$, EtOH or MeOEtOH.

displaying a classical double-reciprocal plot allowing to calculate, in the case of 4,5,6,7-tetraiodobenzimidazole ( $1 \mathbf{a}$ or TIBI), a $K_{\mathrm{i}}$ value of $23 \mathrm{nM}$ (Fig. 1A). Conversely, inhibition is non-competitive with respect to the peptide phosphoacceptor substrate (Fig. 1B) further supporting a mechanism of action implying the occupancy of the nucleotide binding pocket in competition with ATP. Moreover, the performance of compound 1a allows to definitely rank the efficiency of halogens as substituents of the benzene ring, iodine being the best, followed by bromine ( 0.023 vs $0.3 \mu \mathrm{M}$ by comparing, compounds 1a and K17 (also termed TBI) of Table 1) which in turn proved to be about two orders of magnitude more effective than chlorine, 4,5,6,7-tetrachlorobenzimidazole (TCI) exhibiting a $K_{\mathrm{i}}$ value of $21 \mu \mathrm{M}$ under comparable conditions. ${ }^{30}$ This came not as a surprise considering the data already available for di-substituted benzimidazole derivatives in which fluorine was found to be the least effective. ${ }^{16,19}$ However, a deeper analysis of the $K_{\mathrm{i}}$ values of tetraiodinated versus tetrabrominated compounds highlights that the presence of an additional substitution on the imidazole ring may affect not only the absolute potency of the inhibitor but also its relative efficacy with respect to the brominated homologue. In fact, all the four compounds bearing a substitution at position 1 of the imidazole ring (compounds 21, 23, 25 and 27 of Table 1) display a $K_{\mathrm{i}}$ value about one order of magnitude higher than that of derivative 1a having no substitution at that position. Nevertheless, they are still 10 -fold more potent than the correspondent brominated derivatives as it was observed in the case of the un-substituted compound 1a. On the contrary, the added value of the presence of four iodine atoms on the benzene moiety appears to be variably affected by substitutions at position 2 of the imidazole ring. These latter compounds, with very few exceptions, display inhibition constants significantly higher and close to those of the corresponding brominated derivatives. 
Table 1

Inhibition of protein kinase CK2 by iodinated benzimidazole derivatives (A) in comparison to respective brominated compounds (B)

\begin{tabular}{|c|c|c|c|c|c|}
\hline $\begin{array}{l}\text { A } \\
\text { Iodinated compounds }\end{array}$ & $K_{\mathrm{i}}(\mu \mathrm{M})$ & $\begin{array}{l}\text { B } \\
\text { Brominated compounds }\end{array}$ & $K_{\mathrm{i}}(\mu \mathrm{M})$ & Ratio B/A & Imidazole substitution \\
\hline 1a (K88, TIBI) & 0.023 & $\mathrm{~K} 17^{\mathrm{a}, \mathrm{b}}(\mathrm{TBI})$ & 0.30 & 13.04 & None \\
\hline 2a (K105) & 0.16 & - & - & - & None \\
\hline 3a (K104) & 0.10 & - & - & - & None \\
\hline $\mathbf{4 a}(\mathrm{K} 98)$ & 0.46 & - & - & - & None \\
\hline 5a (K106) & 0.59 & - & - & - & None \\
\hline $\mathbf{6 a}(\mathrm{K} 95)$ & 0.075 & - & - & - & None \\
\hline $7 \mathbf{a}(\mathrm{K} 92)$ & 0.024 & - & - & - & $2-\mathrm{CH}_{3}$ \\
\hline $8 \mathbf{a}(\mathrm{K} 99)$ & 0.33 & - & - & - & $2-\mathrm{CH}_{3}$ \\
\hline 9a (K93) & 0.019 & - & - & - & $2-\mathrm{C}_{2} \mathrm{H}_{5}$ \\
\hline 10a (K89) & 0.12 & $\mathrm{~K} 10^{\mathrm{a}}$ & 0.37 & 3.08 & $2-\mathrm{CF}_{3}$ \\
\hline 11a (K94) & 0.07 & $\mathrm{~K} 11^{\mathrm{a}}$ & 0.20 & 2.87 & $2-\mathrm{C}_{2} \mathrm{~F}_{5}$ \\
\hline 12a (K103) & 0.12 & $\mathrm{~K} 21^{\mathrm{a}}$ & 0.25 & 2.08 & $2-\mathrm{Cl}$ \\
\hline 13a (K96) & 0.09 & $\mathrm{~K} 20^{\mathrm{a}}$ & 0.37 & 4.11 & $2-\mathrm{Br}$ \\
\hline 14 (K100) & 0.027 & $\mathrm{~K} 30^{\mathrm{b}}$ & 0.14 & 5.18 & $2-\mathrm{NH}\left(\mathrm{CH}_{2}\right)_{2} \mathrm{OH}$ \\
\hline 15 (K97) & 0.05 & $\mathrm{~K} 22^{\mathrm{a}}$ & 0.20 & 4.00 & $2-\mathrm{SH}$ \\
\hline $16(\mathrm{~K} 101)$ & 0.054 & $\mathrm{~K} 33^{\mathrm{b}}$ & 0.12 & 2.22 & $2-\mathrm{SCH}_{2} \mathrm{COOH}$ \\
\hline 17 (K112) & 0.05 & $\mathrm{~K} 32^{\mathrm{b}}$ & 0.18 & 3.60 & $2=0$ \\
\hline 21 (K107) & 0.14 & 20 (K68) & 1.34 & 9.57 & $1-\mathrm{CH}_{2} \mathrm{COOH}$ \\
\hline 23 (K108) & 0.13 & $22(K 83)$ & 1.45 & 11.15 & $1-\mathrm{CH}_{2} \mathrm{CONH}_{2}$ \\
\hline 25 (K109) & 0.18 & $24(K 84)$ & 1.91 & 10.60 & $1-\mathrm{CH}_{2} \mathrm{CONHCH}_{3}$ \\
\hline 27 (K110) & 0.16 & 26 (K85) & 1.51 & 9.40 & $1-\mathrm{CH}_{2} \mathrm{CONHNH}_{2}$ \\
\hline
\end{tabular}

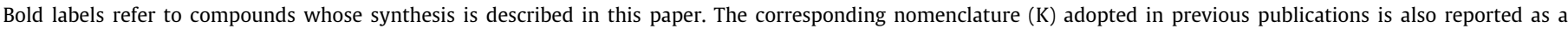
reference.

a Drawn from Andrzejewska et al. ${ }^{27}$

${ }^{b}$ Drawn from Pagano et al. ${ }^{28}$

\subsection{Molecular modeling studies}

Searching for a plausible structural explanation of the superiority of tetraiodinated derivatives as CK2 inhibitors, a molecular modeling approach was undertaken. Starting from the crystal structure of $\mathrm{K} 17$ in complex with $Z m C K 2 \alpha$ subunit (PDB code $2 \mathrm{OXY})^{13}$ we determined the binding mode of compound 1a by a molecular docking strategy, in comparison with that of the tetrabromo (TBI, K17) and tetrachloro (TCI) homologues, using human CK2 as target protein (PDB code: $1 \mathrm{JWH})^{31}$ (Fig. 2). All three inhibitors lay inside the CK2 binding cleft exactly at the same position as $\mathrm{K} 17$ in $\mathrm{ZmCK} 2 \alpha$, revealing identical binding modes. However, compound 1a is able to fill better the CK2 binding cleft due to the increased dimensions of iodine substituents with respect to bromine and chlorine. To better validate this hypothesis we calculated the percentage of human CK2 ATP-binding cleft occupancy (occupancy factor, OF) by the three analogs. The CK2 ATP-binding pocket volume was calculated as described in Section 3 by using the apo crystal structure $1 \mathrm{JWH}$ plus one conserved water molecule. ${ }^{13}$ The OF values were calculated relative to the binding cleft and the inhibitor's volume. As also shown in Fig. 2, TCI shows a low binding cleft OF value (69\%), and tetrabromine substitution is responsible of an increased occupancy up to $75 \%$ while the most potent inhibitor 1a (TIBI), bearing the iodine substitution, fills by 86\% the CK2 ATP-binding pocket. Almost identical conclusions can be drawn by comparing the increased hydrophobicity with the increased inhibitory potency of the tetrahalogenated derivatives. Moreover, iodine atoms of derivative 1a are able to perform stronger halogen bonds with the binding cleft, in particular with the backbone carbonyls of Glu114 and Val116 of the hinge region. ${ }^{13}$ In fact, even if all four halogen atoms are capable of acting as halogen bond donors, iodine usually forms the strongest interactions, followed by bromine and chlorine atoms, respectively. ${ }^{32}$ The same arguments apply also to the other tetraiodobenzimidazole derivatives considered in this paper, all displaying in general an inhibitory efficiency higher than that of their brominated counterparts. Note, however, that a double mutant of CK2 in which two bulky residues of the hydrophobic pocket have been replaced by smaller ones (V66I174AA) undergoes a 70- and 16-fold reduced inhibition by compounds $\mathbf{1 a}$ and TBI, respectively (data not shown). This corroborates the view that, a part from halogen bonds, occupancy and hydrophobic interactions play a crucial role in optimizing the performance of tetraiododerivatives.

\section{Experimental}

\subsection{Chemical synthesis}

\subsubsection{General procedure}

All chemicals and solvents were purchased from Sigma-Aldrich. Melting points (uncorr.) were measured in open capillary tubes on a Gallenkamp-5 melting point apparatus. Ultraviolet absorption spectra were recorded on Kontron Uvikon 940 spectrophotometer. ${ }^{1} \mathrm{H}$ NMR spectra (in ppm) were measured with Varian Gemini $200 \mathrm{MHz}$ (or Varian UNITYplus $500 \mathrm{MHz}$ ) spectrometer at $298 \mathrm{~K}$ in DMSO- $d_{6}$ using tetramethylsilane as internal standard. Massspectra $(70 \mathrm{eV})$ were obtained with AMD-604 (Intectra) spectrometer. Flash chromatography was performed with Merck silica gel 60 (200-400 mesh). Elemental analyses of the new compounds were within $\pm 0.4 \%$ of the respective theoretical values.

\subsubsection{General procedure for iodination of benzimidazole derivatives}

The amounts of reagents used for the preparation of tetraiodobenzimidazoles were according below described procedure. For diiodo- or triiodo-derivatives amounts of iodine and periodic acid were, respectively, reduced.

Periodic acid $(2.28 \mathrm{~g}, 10 \mathrm{mmol})$ was dissolved in concd $\mathrm{H}_{2} \mathrm{SO}_{4}$ $(50 \mathrm{~mL})$. Finely powdered iodine $(10.1 \mathrm{~g}, 40 \mathrm{mmol})$ was added to the solution. After $20 \mathrm{~min}$ of stirring the homogenous mixture was placed in ice bath. Next, the respective benzimidazole (10 mmol) was slowly added (exothermic reaction). The reaction mixture was stirred at room temperature for $1 \mathrm{~h}$ and then has been heated to the final $\left(60^{\circ} \mathrm{C}\right)$ temperature. After next $2 \mathrm{~h}$ the mixture was poured onto crushed ice. The resulting dark solid was filtered off, added to the solution of sodium dithionite $(25 \mathrm{~mL}, 10 \%)$ and 

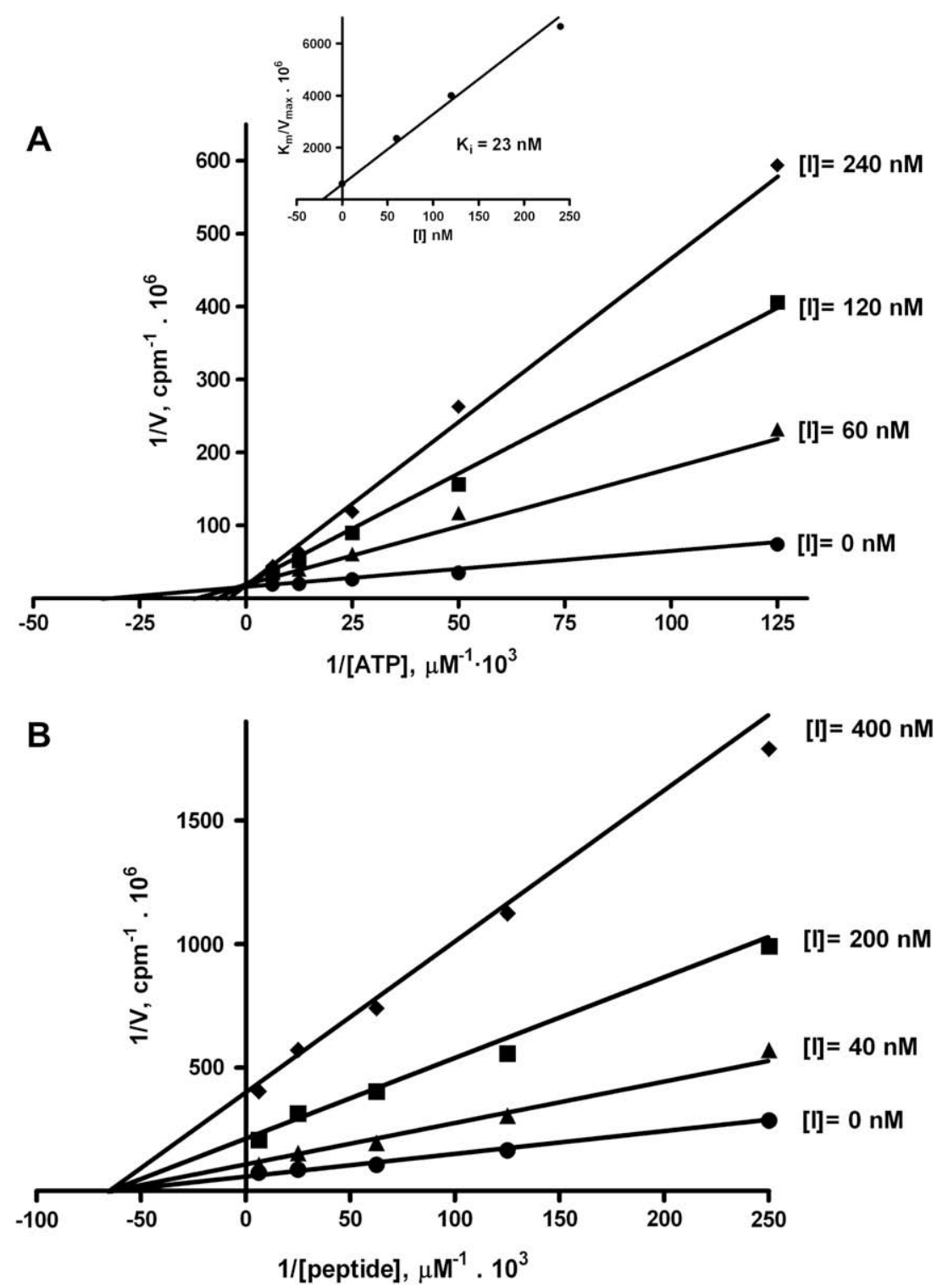

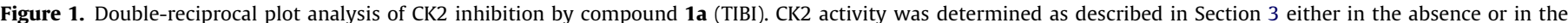

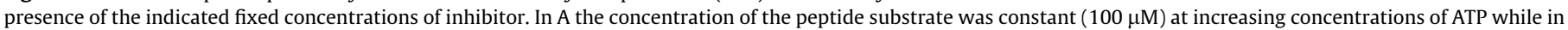

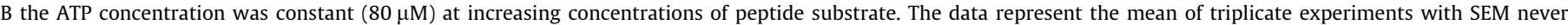

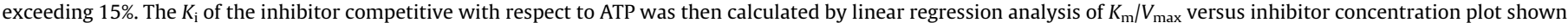
in the inset of panel $A$.

stirred for $10 \mathrm{~min}$. The crude product was dissolved in EtOH/2 M $\mathrm{NaOH}(1: 1)$ and filtered. The pale yellow or green filtrate was brought to $\mathrm{pH} 4-5$ with acetic acid to yield respective iodinated benzimidazole as yellow or yellowish chromatographically pure precipitate. For analysis and biological investigation small amounts were crystallized from $\mathrm{EtOH}, \mathrm{MeOEtOH}$, dioxane, $\mathrm{DMF} /$ dioxane or purified by alkalization and precipitation with acetic acid from organic solvent-water mixtures.

\subsubsection{4,5,6,7-Tetraiodo-1H-benzimidazole (1a)}

From benzimidazole as described above: (mp 296-299 ${ }^{\circ} \mathrm{C}$ (decomp.) $\mathrm{I}_{2}$ evol. $>250{ }^{\circ} \mathrm{C}, 77 \%$. A sample for analysis was crystallized from DMF/dioxane. UV (MeOH): 233 (28,600), 275 (9900), 295 $(10,300) .{ }^{1} \mathrm{H}$ NMR $\left(\mathrm{Me}_{2} \mathrm{SO}-d_{6}\right) \delta(\mathrm{ppm}): 8.21(\mathrm{~s}, 1 \mathrm{H}, \mathrm{H}-\mathrm{C}), 12.85$ (br s, $1 \mathrm{H}, \mathrm{H}-\mathrm{N})$. MS m/z: $623\left(9, \mathrm{M}^{+}+1\right), 622\left(100, \mathrm{M}^{+}\right), 495(16$, $\left.\mathrm{M}^{+}-127\right), 368$ (22, $\left.\mathrm{M}^{+}-254\right)$. Anal. Calcd for $\mathrm{C}_{7} \mathrm{H}_{2} \mathrm{I}_{4} \mathrm{~N}_{2}$ (621.72): $\mathrm{C}$, 13.52; H, 0.32; N, 4.51. Found: C, 13.67; H, 0.44; N, 4.40 .

\subsubsection{5 -Chloro-4,6,7-triiodo-1H-benzimidazole (2a)}

As described above starting from 5-chloro-benzimidazole. Mp $256-259{ }^{\circ} \mathrm{C}$ (with decomp.), 65\%. A sample for analysis was crystallized from EtOH. UV (MeOH): 230 (23,300), 281 (14,300), 305 (sh, 5800). ${ }^{1} \mathrm{H}$ NMR $\left(\mathrm{Me}_{2} \mathrm{SO}-d_{6}\right) \delta$ (ppm): $8.32(\mathrm{~s}, \mathrm{H}-\mathrm{C}), 13.05$ (br s, H-N). MS m/z: $532\left(33, \mathrm{M}^{+}+2\right), 530\left(100, \mathrm{M}^{+}\right), 440$ (19, $\left.\mathrm{M}^{+}-70\right), 438\left(22, \mathrm{M}^{+}-22\right), 403\left(\mathrm{M}^{+}-127\right)$. Anal. Calcd for $\mathrm{C}_{7} \mathrm{H}_{2} \mathrm{ClI}_{3} \mathrm{~N}_{2}$ (530.27): C, 15.86; H, 0.38; N, 5.28. Found: C, 15.88; $\mathrm{H}, 0.40 ; \mathrm{N}, 5.32$.

\subsubsection{5-Bromo-4,6,7-triiodo-1H-benzimidazole (3a)}

As described above starting from 5-bromo-benzimidazole. Mp $253-255^{\circ} \mathrm{C}$ (with decomp.), 65\%. A sample for analysis was crystallized from methoxyethanol. UV (MeOH): 236 (19,500), 282 (12,900), 305 (sh, 5600). ${ }^{1} \mathrm{H}$ NMR $\left(\mathrm{Me}_{2} \mathrm{SO}-d_{6}\right) \delta$ (ppm): 8.28 (s, $1 \mathrm{H}, \mathrm{H}-\mathrm{C}), 13.0$ (br s, $1 \mathrm{H}, \mathrm{H}-\mathrm{N})$. MS $m / z$ : $576\left(\mathrm{M}^{+}+1\right), 574\left(\mathrm{M}^{+}-1\right)$, $482\left(32, \mathrm{M}^{+}-93\right), 449\left(15, \mathrm{M}^{+}-126\right), 447\left(\mathrm{M}^{+}-128\right)$. Anal. Calcd 

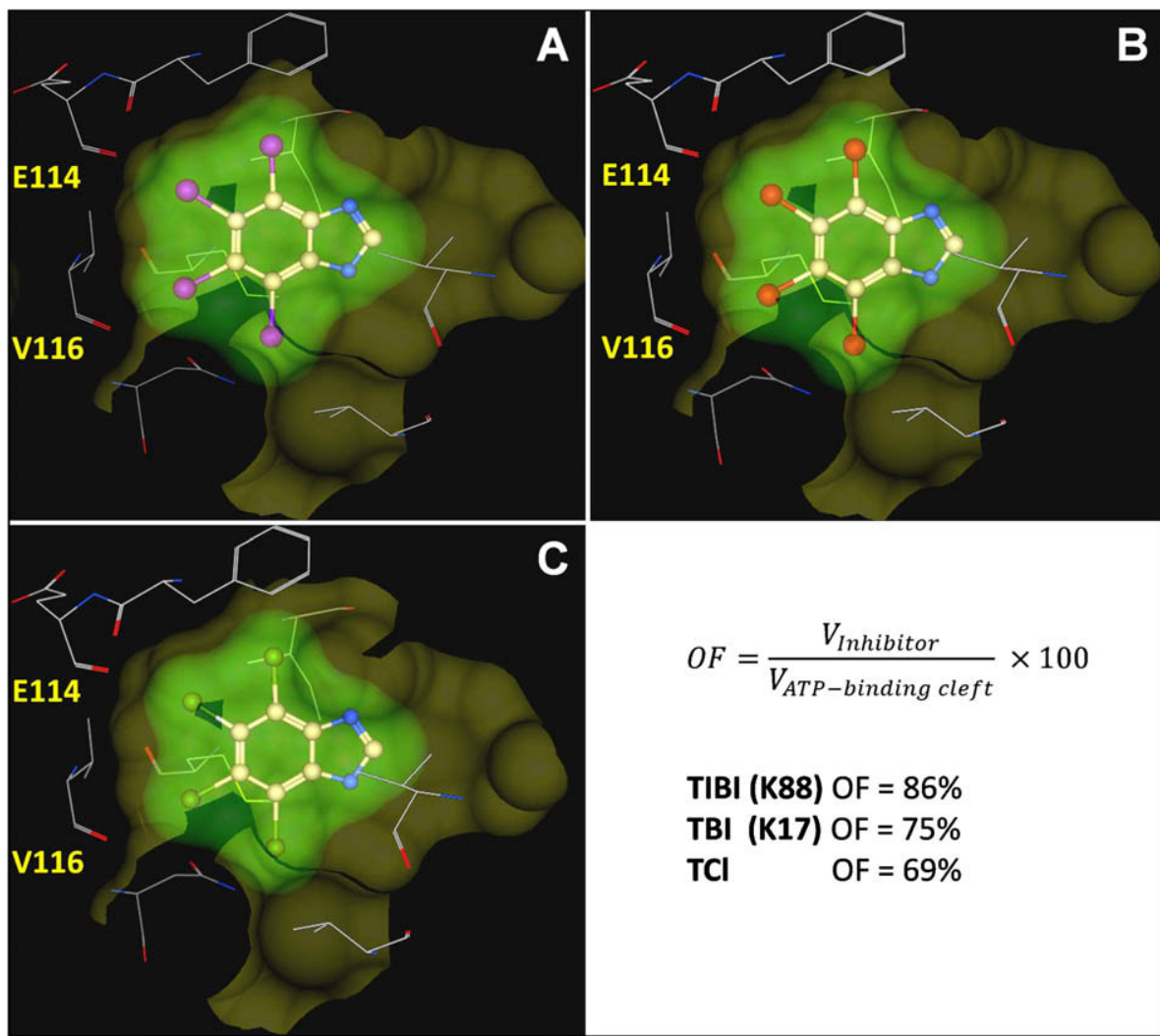

$O F=\frac{V_{\text {Inhibitor }}}{V_{\text {ATP-binding cleft }}} \times 100$

TIBI (K88) OF = 86\%

TBI (K17) OF $=75 \%$

TC

$\mathrm{OF}=69 \%$

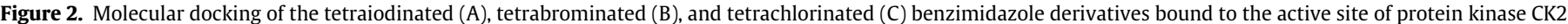

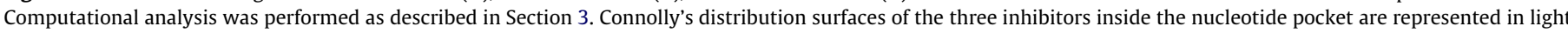
green. The occupancy factor (OF) values, discussed in the text, are also indicated.

for $\mathrm{C}_{7} \mathrm{H}_{2} \mathrm{BrI}_{3} \mathrm{~N}_{2}$ (574.72): C, 14.63; $\mathrm{H}, 0.35 ; \mathrm{N}, 4.87$. Found: C, 14.50; $\mathrm{H}, 0.42 ; \mathrm{N}, 4.76$.

\subsubsection{5,6 -Dichloro-4,7-diiodo-1H-benzimidazole (4a)}

As described above from 5,6-dichloro-benzimidazole. Mp 271$273{ }^{\circ} \mathrm{C}$ (with decomp.), 70\%. A sample for analysis was crystallized from EtOH. UV (MeOH): 229 (23,000), 278 (19,000), $302(9500) .{ }^{1} \mathrm{H}$ NMR $\left(\mathrm{Me}_{2} \mathrm{SO}-d_{6}\right) \delta(\mathrm{ppm}): 8.40(\mathrm{~s}, 1 \mathrm{H}, \mathrm{H}-\mathrm{C}), 13.2$ (br s, $\left.1 \mathrm{H}, \mathrm{H}-\mathrm{N}\right)$. MS m/z: $442\left(10, \mathrm{M}^{+}+4\right), 440\left(63, \mathrm{M}^{+}+2\right), 438\left(100, \mathrm{M}^{+}\right), 311$ $\left(\mathrm{M}^{+}\right.$-127). Anal. Calcd for $\mathrm{C}_{7} \mathrm{H}_{2} \mathrm{Cl}_{2} \mathrm{I}_{2} \mathrm{~N}_{2}$ (438.82): C, 19.16; $\mathrm{H}, 0.46$; $\mathrm{N}, 6.38$. Found: C, 19.19; H, 0.55; N, 6.23.

\subsubsection{4,6-Dichloro-5,7-diiodo-1H-benzimidazole (5a)}

As described above from 4,6-dichloro-benzimidazole. Mp 254$256{ }^{\circ} \mathrm{C}, 42 \%$. A sample for analysis was crystallized from EtOH. UV (MeOH): 236 (22,500), 273 (8700), 302 (4400). ${ }^{1} \mathrm{H}$ NMR $\left(\mathrm{Me}_{2} \mathrm{SO}_{-} d_{6}\right)$ $\delta$ (ppm): 8.39 (s, $1 \mathrm{H}, \mathrm{H}-\mathrm{C}), 13.08$ and 13.48 (br s, $1 \mathrm{H}, \mathrm{H}-\mathrm{N}$ ). MS m/z: $440\left(28, \mathrm{M}^{+}+1\right), 438\left(100, \mathrm{M}^{+}-1\right), 313\left(12, \mathrm{M}^{+}-126\right), 311$ (13, $\mathrm{M}^{+}$-128). Anal. Calcd for $\mathrm{C}_{7} \mathrm{H}_{2} \mathrm{Cl}_{2} \mathrm{I}_{2} \mathrm{~N}_{2}$ (438.82): $\mathrm{C}, 19.16 ; \mathrm{H}, 0.46$; N, 6.38: Found: C, 19.14; $\mathrm{H}, 0.44 ; \mathrm{N}, 6.34$.

\subsubsection{4,6-Dibromo-5,7-diiodo-1H-benzimidazole (6a)}

As described above from 4,6-dibromo-benzimidazole. Mp 309$311{ }^{\circ} \mathrm{C}$ (with decomp.), 70\%. A sample for analysis was crystallized from dioxane. UV (MeOH): 236 (21,300), 277 (11,700), 303 (sh, 4200). ${ }^{1} \mathrm{H}$ NMR $\left(\mathrm{Me}_{2} \mathrm{SO}-d_{6}\right) \delta(\mathrm{ppm}): 8.34(\mathrm{~s}, 1 \mathrm{H}, \mathrm{H}-\mathrm{C}), 13.09$ and 13.23 (br s, $1 \mathrm{H}, \mathrm{H}-\mathrm{N})$. MS m/z: $529\left(47\left(\mathrm{M}^{+}+2\right), 527\left(100, \mathrm{M}^{+}\right), 525\right.$ (48, $\left.\mathrm{M}^{+}-2\right), 400\left(\mathrm{M}^{+}-127\right)$. Anal. Calcd for $\mathrm{C}_{7} \mathrm{H}_{2} \mathrm{Br}_{2} \mathrm{I}_{2} \mathrm{~N}_{2}$ (527.72): $\mathrm{C}$, 15.93; H, 0.38; N, 5.31. Found: C, 15.90; H, 0.47; N, 5.22.

\subsubsection{2-Methyl-4,5,6,7,-tetraiodo-1H-benzimidazole (7a)}

As described above from 2-methyl-benzimidazole: Mp 289$291{ }^{\circ} \mathrm{C}, 69 \%$. A sample for analysis was crystallized from dioxane.
UV (MeOH): 234 (29,300), 277 (10,300), 292 (10,500). ${ }^{1} \mathrm{H}$ NMR $\left(\mathrm{Me}_{2} \mathrm{SO}-d_{6}\right) \delta(\mathrm{ppm}): 2.47$ (s, 3H, $\left.\mathrm{H}_{3} \mathrm{C}\right), 12.5$ (br s, $\left.1 \mathrm{H}, \mathrm{H}-\mathrm{N}\right) . \mathrm{MS}$ $m / z: 637\left(10, \mathrm{M}^{+}+1\right), 636\left(100, \mathrm{M}^{+}\right), 509\left(17\left(\mathrm{M}^{+}-127\right), 382\right.$ $\left(\mathrm{M}^{+}-254\right)$. Anal. Calcd for $\mathrm{C}_{8} \mathrm{H}_{4} \mathrm{I}_{4} \mathrm{~N}_{2}$ (635.75): $\mathrm{C}, 15.11 ; \mathrm{H}, 0.63 ; \mathrm{N}$ 4.41. Found: C, 15.09 ; H, 0.73; N, 4.27 .

\subsubsection{5,6-Dichloro-4,7-diiodo-2-methyl-1H-benzimidazole (8a)}

As described above from 5,6-dichloro-2-methylbenzimidazole. Mp $288-290^{\circ} \mathrm{C}$ (with decomp.), 52\%. A sample for analysis was crystallized from EtOH. UV (MeOH): 234 (23,500), 275 (18,300), 303 (8500). ${ }^{1} \mathrm{H}$ NMR $\left(\mathrm{Me}_{2} \mathrm{SO}-d_{6}\right) \delta(\mathrm{ppm}): 2.52$ (s, 3H, $\left.\mathrm{H}_{3} \mathrm{C}\right), 12.8$ (br s, 1H, H-N). MS m/z: $456\left(11, \mathrm{M}^{+}+4\right), 454\left(56, \mathrm{M}^{+}+2\right), 452$ $\left(100, \mathrm{M}^{+}\right), 311\left(\mathrm{M}^{+}-127\right)$. Anal. Calcd for $\mathrm{C}_{8} \mathrm{H}_{4} \mathrm{Cl}_{2} \mathrm{I}_{2} \mathrm{~N}_{2}$ (452.85): $\mathrm{C}$, 21.22; H, 0.89; N, 6.19. Found: C, 21.15; H, 0.95; N, 6.08.

\subsubsection{2-Ethyl-4,5,6,7-tetraiodo-1H-benzimidazole (9a)}

As described above from 2-ethyl-benzimidazole. Mp 261$262{ }^{\circ} \mathrm{C}$ (from EtOH), 68\%. UV (MeOH): 237 (28,500), 277 (9700), $293(11,100) .{ }^{1} \mathrm{H}$ NMR $\left(\mathrm{Me}_{2} \mathrm{SO}-d_{6}\right) \delta(\mathrm{ppm}): 1.28\left(\mathrm{t}, 3 \mathrm{H}, \mathrm{H}_{3} \mathrm{C}\right.$ $J=7.6 \mathrm{~Hz}$ ), 2.82 (q, 2H, $\left.\mathrm{H}_{2} \mathrm{C}, J=7.6 \mathrm{~Hz}\right), 12.6$ (br s, $\left.1 \mathrm{H}, \mathrm{H}-\mathrm{N}\right) . \mathrm{MS}$ $m / z: 637\left(10, \mathrm{M}^{+}+1\right), 636\left(100, \mathrm{M}^{+}\right), 509\left(17\left(\mathrm{M}^{+}-127\right), 382\right.$ $\left(\mathrm{M}^{+}-254\right)$. Anal. Calcd for $\mathrm{C}_{9} \mathrm{H}_{6} \mathrm{I}_{4} \mathrm{~N}_{2}$ (649.76): C, 16.64; $\mathrm{H}, 0.93 ; \mathrm{N}$, 4.31. Found: C, 16.59; H, 0.99; N, 4.20.

\subsubsection{4,5,6,7-Tetraiodo-2-trifluoromethyl-1H-benzimidazole (10a)}

As described above from 2-trifluoromethylbenzimidazole $\mathrm{Mp}$ $240-242{ }^{\circ} \mathrm{C}$ (with decomp.) (from MeOEtOH), 38\%. UV (MeOH): 237 (35,200), 283 (10,000), 303 (9900). ${ }^{1} \mathrm{H}$ NMR $\left(\mathrm{Me}_{2} \mathrm{SO}-d_{6}\right) \delta$ (ppm): 14.4 (br s, H-N). MS m/z: 690 (5, $\left.\mathrm{M}^{+}+1\right), 689\left(100, \mathrm{M}^{+}\right), 563$ (16, $\left.\mathrm{M}^{+}-126\right), 436\left(20, \mathrm{M}^{+}-253\right)$. Anal. Calcd for $\mathrm{C}_{8} \mathrm{HF}_{3} \mathrm{I}_{4} \mathrm{~N}_{2}$ (689.72): C, 13.93; H, 0.15; N, 4.31. Found: C, 13.78; H, 0.24; N, 4.20. 
3.1.13. 2-Pentafluoroethyl-4,5,6,7-tetraiodo-1H-benzimidazole (11a)

As described above from 2-pentafluoroethylbenzimidazole. Mp 247-249 ${ }^{\circ} \mathrm{C}$ (with decomp.), 48\% (from EtOH). UV (MeOH): 237 (36,100), 284 (11,000), 304 (11,200). ${ }^{1} \mathrm{H}$ NMR $\left(\mathrm{Me}_{2} \mathrm{SO}-d_{6}\right) \delta$ (ppm): 14.3 (br s, $1 \mathrm{H}, \mathrm{H}-\mathrm{N})$. MS m/z: $741\left(10, \mathrm{M}^{+}+1\right), 740$ (100, $\left.\mathrm{M}^{+}\right), 613\left(16, \mathrm{M}^{+}-127\right), 486\left(20, \mathrm{M}^{+}-254\right)$. Anal. Calcd for $\mathrm{C}_{9} \mathrm{HF}_{5} \mathrm{I}_{4} \mathrm{~N}_{2}$ (739.73): C, 14.61; $\mathrm{H}, 0.14 ; \mathrm{N}, 3.79$. Found: $\mathrm{C}, 14.51 ; \mathrm{H}$, $0.22 ; \mathrm{N}, 3.64$.

\subsubsection{2-Chloro-4,5,6,7-tetraiodo-1H-benzimidazole (12a)}

As described above from 2-chlorobenzimidazole. Mp 303$306{ }^{\circ} \mathrm{C}$ (with decomp., $>250{ }^{\circ} \mathrm{C} \mathrm{I}_{2}$ evol.), $37 \%$. A sample for analysis was crystallized from DMF/dioxane. UV (MeOH): 235 (35,200), 275 (12,200) 295 (12,000), 315 (sh). ${ }^{1} \mathrm{H}$ NMR $\left(\mathrm{Me}_{2} \mathrm{SO}-d_{6}\right) \delta$ (ppm): 13.7 (br s, $1 \mathrm{H}, \mathrm{H}-\mathrm{N})$. MS m/z: $658\left(42, \mathrm{M}^{+}+2\right), 656\left(100, \mathrm{M}^{+}\right), 529(24$, $\left.\mathrm{M}^{+}-127\right), 402$ (35, $\left.\mathrm{M}^{+}-254\right)$. Anal. Calcd for $\mathrm{C}_{7} \mathrm{HCll}_{4} \mathrm{~N}_{2}$ (656.17): C, $12.81 ; \mathrm{H}, 0.15 ; \mathrm{N}, 4.00$. Found: C, 12.75; H, 0.20; N, 3.92.

\subsubsection{2-Bromo-4,5,6,7-tetraiodo- $1 \mathrm{H}$-benzimidazole (13a)}

As described above from 2-bromobenzimidazole: Mp 296$299{ }^{\circ} \mathrm{C}$, $\left(\mathrm{I}_{2}\right.$ evol. $\left.>230^{\circ} \mathrm{C}\right), 88 \%$. A sample for analysis was crystallized from DMF/dioxane. UV (MeOH): 239 (28,100), 273 (12,100), 300 (12,700). ${ }^{1} \mathrm{H}$ NMR $\left(\mathrm{Me}_{2} \mathrm{SO}-d_{6}\right) \delta(\mathrm{ppm}): 13.6$ (br s, $\left.1 \mathrm{H}, \mathrm{H}-\mathrm{N}\right)$. MS m/z: $701\left(96, \mathrm{M}^{+}\right), 699\left(\mathrm{M}^{+}-2\right), 574\left(19, \mathrm{M}^{+}-127\right), 572$ (17, $\mathrm{M}^{+}$-129). Anal. Calcd for $\mathrm{C}_{7} \mathrm{HBrI}_{4} \mathrm{~N}_{2}$ (700.62): C, 12.00; $\mathrm{H}, 0.14$; N, 4.00. Found: C, 12.00; H, 0.19; N, 3.84.

\subsubsection{2-[(2-Hydroxyethyl)amino)]-4,5,6,7-tetraiodo- $1 H$ - benzimidazole (14)}

To a mixture of 13a (600 mg, $0.85 \mathrm{mmol})$ in $\mathrm{MeOEtOH}(15 \mathrm{~mL})$, ethanoloamine ( $2 \mathrm{~g}, 2 \mathrm{~mL}, 33 \mathrm{mmol}$ ) was added. The reaction mixture was stirred and heated at $110-115^{\circ} \mathrm{C}$ (bath temp) for $10 \mathrm{~h}$. The reaction mixture was diluted with water $(20 \mathrm{~mL})$ and brought to $\mathrm{pH} 4-5$. The precipitate was filtered and deposited on silica gel column $(2 \times 12 \mathrm{~cm})$. Chromatography was performed with $\mathrm{CHCl}_{3}$ $(200 \mathrm{~mL})$ and $\mathrm{CHCl}_{3}-\mathrm{MeOH}(95: 5, \mathrm{v} / \mathrm{v})$. The product containing fractions were evaporated to dryness and the residue crystallized from dioxane-water to give pale yellow powder (320 mg, 55\%); mp 249-251 ${ }^{\circ} \mathrm{C}$. UV (MeOH): 244 (35,200), 274 (13,300), 315 $(12,200) .{ }^{1} \mathrm{H}$ NMR $\left(\mathrm{Me}_{2} \mathrm{SO}-d_{6}\right) \delta(\mathrm{ppm}): 3.40$ (q, 2H, $\mathrm{H}_{2} \mathrm{C}$, $J=5.6 \mathrm{~Hz}$ ), $3.57\left(\mathrm{t}, 2 \mathrm{H}, \mathrm{H}_{2} \mathrm{C}, J=5.5 \mathrm{~Hz}\right), 5.01$ (br s, $\left.1 \mathrm{H}, \mathrm{HO}\right), 6.45(\mathrm{t}$, $1 \mathrm{H}, \mathrm{H}-\mathrm{N}-\mathrm{CH}_{2}, \mathrm{~J}=6.6 \mathrm{~Hz}$ ), 10.9 (br s, $1 \mathrm{H}, \mathrm{H}-\mathrm{N}$-imid.). MS m/z: 681 $\left(5, \mathrm{M}^{+}+1\right), 680\left(100, \mathrm{M}^{+}\right), 662\left(19, \mathrm{M}^{+}-18\right), 637\left(100, \mathrm{M}^{+}-43\right)$, 510 (60, $\left.\mathrm{M}^{+}-170\right)$. Anal Calcd for $\mathrm{C}_{9} \mathrm{H}_{7} \mathrm{~N}_{3} \mathrm{I}_{4} \mathrm{O}$ (680.79): C, 15.88; H, 1.04; N, 6.17. Found: $15.91 ; \mathrm{H}, 1.15 ; \mathrm{N}, 6.06$.

\subsubsection{7. $4,5,6,7-T e t r a i o d o-1 H, 3 H-d i h y d r o-2 H$-benzimidazole-2- thione (15)}

To the stirred solution of 13a (700 mg, $1 \mathrm{mmol}$ ) in MeOEtOH $(25 \mathrm{~mL})$ thiourea $(156 \mathrm{mg}, 2 \mathrm{mmol})$ was added. The reaction mixture was stirred and heated at $105-110{ }^{\circ} \mathrm{C}$ (bath temp) for $14 \mathrm{~h}$. A precipitate formed was filtered, dissolved in $\mathrm{EtOH} / 0.2 \mathrm{M}$ aq. $\mathrm{NaOH}(1: 1, \mathrm{v} / \mathrm{v})$ and precipitated by addition of acetic acid to $\mathrm{pH}$ 4-5 to give as pale yellow chromatographically pure precipitate (520 mg, 80\%); $\mathrm{mp}$ (decomp. $>290{ }^{\circ} \mathrm{C}$ with $\mathrm{I}_{2}$ evol.) (for analysis crystallized from MeOEtOH-water). UV (MeOH): 222 (18,600), 264 (35,450), 336 (20,500). ${ }^{1} \mathrm{H}$ NMR $\left(\mathrm{Me}_{2} \mathrm{SO}-d_{6}\right) \delta$ (ppm): 12.8 (br $\mathrm{s}, 1 \mathrm{H}, \mathrm{H}-\mathrm{N})$. MS $m / z$ : $655\left(5, \mathrm{M}^{+}+2\right), 654\left(9, \mathrm{M}^{+}+1\right), 653\left(100, \mathrm{M}^{+}\right)$, $527\left(\mathrm{M}^{+}-126\right), 400\left(\mathrm{M}^{+}-253\right)$. Anal Calcd for $\mathrm{C}_{7} \mathrm{H}_{2} \mathrm{~N}_{2} \mathrm{I}_{4} \mathrm{~S}$ (653.78): C, 12.86; H, 0.31; N, 4.28. Found: C, 12.95; H, 0.42; N, 4.13.

\subsubsection{8. (4,5,6,7-Tetraiodo-1H-benzimidazol-2-ylsulfanyl)-acetic} acid (16)

The mixture of 2-mercapto-4,5,6,7-tetraiodo-1H-benzimidazole (751 mg, $1.15 \mathrm{mmol}), \mathrm{K}_{2} \mathrm{CO}_{3}(1 \mathrm{~g})$, bromoacetic acid (400 mg,
$2,87 \mathrm{mmol}$ ) in butanone $(45 \mathrm{~mL})$ was refluxed for $6 \mathrm{~h}$. The insolubilities were filtered off and washed with $50 \mathrm{~mL}$ of hot butanone. The filtrate was evaporated to dryness. The residue was crystallized from dioxane; mp 274-276 (decomp. >240); yield 70\% (4.98 g). UV (MeOH: 254 (13,100), 309 (12,300). ${ }^{1} \mathrm{H}$ NMR $\left(\mathrm{Me}_{2} \mathrm{SO}-d_{6}\right) \delta(\mathrm{ppm})$ : 4.16 (s, 2H, $\mathrm{H}_{2} \mathrm{C}$ ), 12.9 (br s, $1 \mathrm{H}, \mathrm{HO}$ ). TOF MS ES ${ }^{+}: 712.6257$ $\left(\mathrm{M}^{+}+\mathrm{H}^{+}, 712.6251\right)$. Anal. Calcd for $\mathrm{C}_{9} \mathrm{H}_{4} \mathrm{I}_{4} \mathrm{~N}_{2} \mathrm{O}_{2} \mathrm{~S}$ (711.83): C, 15.19; $\mathrm{H}, 0.57$; N, 4.50. Found: C, 15.20; $\mathrm{H}, 0.51 ; \mathrm{N}, 4.43$.

\subsubsection{4,5,6,7-Tetraiodo- $1 H, 3 H$-dihydro- $2 H$-benzimidazole-2- one (17)}

The stirred mixture of 13a (700 mg, $1 \mathrm{mmol}$ ), anhyd sodium acetate $(410 \mathrm{mg}, 5 \mathrm{mmol}$ ) in anhyd acetic acid was refluxed for $20 \mathrm{~h}$. The mixture was cooled, the formed precipitate was filtered and washed few times with EtOH-water (1:1). The product (608 mg, 95\%) was chromatographically pure. For analytical and biological investigation small amount was crystallized from EtOH/dioxane; $\mathrm{mp}>310^{\circ} \mathrm{C}$ (decomp.) UV (MeOH): 236 (36,900), 306 (6400). ${ }^{1} \mathrm{H}$ NMR $\left(\mathrm{Me}_{2} \mathrm{SO}-d_{6}\right) \delta$ (ppm): 11.04 (s, H-N-imid.). MS $m / z: 639\left(9, \mathrm{M}^{+}+1\right), 638\left(100, \mathrm{M}^{+}\right), 512\left(25\left(\mathrm{M}^{+}-128\right), 384\right.$ (27, $\left.\mathrm{M}^{+}-256\right)$. Anal Calcd for $\mathrm{C}_{7} \mathrm{H}_{2} \mathrm{~N}_{2} \mathrm{I}_{4} \mathrm{O}$ (637.72): C, 13.18; $\mathrm{H}$, 0.32 ; N, 4.39. Found: C, 13.37; H, 0.38; N, 4.26.

\subsubsection{0. (4,5,6,7-Tetrabromo-1H-benzimidazol-1-yl)-acetic acid ethyl ester (18)}

Similarly to $\mathbf{1 6}$ butanone was used as a solvent at reflux condition for $5 \mathrm{~h}$. Instead of bromoacetic acid ethyl ester of this acid was used (mp 199-200 $\left.{ }^{\circ} \mathrm{C}, 80 \%\right)$. UV (MeOH): 228 (35,900), 264 (11,900), 272 (11,800), 302 (4100). ${ }^{1} \mathrm{H} \mathrm{NMR}\left(\mathrm{Me}_{2} \mathrm{SO}-d_{6}\right) \delta$ (ppm): $1.23\left(\mathrm{t}, 3 \mathrm{H}, \mathrm{H}_{3} \mathrm{C}, J=7.1 \mathrm{~Hz}\right), 4.19\left(\mathrm{q}, 2 \mathrm{H}, \mathrm{H}_{2} \mathrm{C}, J=7.1 \mathrm{~Hz}\right), 5.29(\mathrm{~s}$, $\left.2 \mathrm{H}, \mathrm{H}_{2} \mathrm{C}-\mathrm{N}\right), 8.32$ (s, $\left.1 \mathrm{H}, \mathrm{H}-\mathrm{C}\right)$. MS $m / z$ : $524\left(16, \mathrm{M}^{+}+4\right), 522$ (65, $\left.\mathrm{M}^{+}+2\right), 520\left(100, \mathrm{M}^{+}\right), 518\left(67, \mathrm{M}^{+}-2\right), 516\left(17, \mathrm{M}^{+}-4\right)$. Anal. Calcd for $\mathrm{C}_{11} \mathrm{H}_{8} \mathrm{Br}_{4} \mathrm{~N}_{2} \mathrm{O}_{2}$ (519.81): C, 25.42; $\mathrm{H}, 1.55 ; \mathrm{N}, 5.39$. Found: C, 25.44; H, 1.56; N, 5.35 .

\subsubsection{1. (4,5,6,7-Tetraiodo-1H-benzimidazol-1-yl)-acetic acid ethyl ester (19)}

Similarly to 18 butanone and bromoacetic acid ethyl ester were used at reflux condition for $5 \mathrm{~h}$ : (mp $\left.224^{\circ} \mathrm{C}, 77 \%\right)$. UV (MeOH): 236 (32,500), 279 (11,400), 299 (10,800). ${ }^{1} \mathrm{H} \mathrm{NMR}\left(\mathrm{Me}_{2} \mathrm{SO}-d_{6}\right) \delta(\mathrm{ppm})$ : $1.23\left(\mathrm{t}, 3 \mathrm{H}, \mathrm{H}_{3} \mathrm{C}, J=7.1 \mathrm{~Hz}\right), 4.19$ (q, 2H, $\left.\mathrm{H}_{2} \mathrm{C}, J=7.1 \mathrm{~Hz}\right), 5.29(\mathrm{~s}, 2 \mathrm{H}$, $\left.\mathrm{H}_{2} \mathrm{C}-\mathrm{N}\right), 8.32(\mathrm{~s}, 1 \mathrm{H}, \mathrm{H}-\mathrm{C})$. MS m/z: $709\left(13, \mathrm{M}^{+}+1\right), 708\left(100, \mathrm{M}^{+}\right)$, 635 (14, $\left.\mathrm{M}^{+}-73\right), 553\left(20, \mathrm{M}^{+}-155\right)$. Anal. Calcd for $\mathrm{C}_{11} \mathrm{H}_{8} \mathrm{I}_{4} \mathrm{~N}_{2} \mathrm{O}_{2}$ (707.82): C, 18, 67; H, 1.14; N, 4.52. Found: C, 18.65; H, 1.18; N, 4.39.

\subsubsection{2. (4,5,6,7-Tetrabromo-1H-benzimidazol-1-yl)-acetic acid (20)}

The suspension of $\mathbf{1 8}(520 \mathrm{mg}, 1 \mathrm{mmol})$ in solution of $\mathrm{KOH}$ $(280 \mathrm{mg}, 5 \mathrm{mmol})$ in ethanol/water $(3: 1, \mathrm{v} / \mathrm{v}, 16 \mathrm{~mL})$ was stirred at room temperature for $3 \mathrm{~h}$. After two hours the mixture became clear. The solution was brought to $\mathrm{pH} 2-3$ with concd $\mathrm{HCl}$. The white chromatographically pure precipitate was filtered and washed with water (390 mg, 79\%). A sample for analysis and biological purposes was crystallized from dioxane-water gave white crystals with no melting point until $300{ }^{\circ} \mathrm{C}$ (melt. and decomp. $>315^{\circ} \mathrm{C}$ ). UV (MeOH): 228 (28,500), 265 (9800), 272 (9900), 302 (3500). ${ }^{1} \mathrm{H}$ NMR (DMSO-d $\left.d_{6}\right): 5.36\left(\mathrm{~s}, \mathrm{CH}_{2}\right), 8.32(\mathrm{~s}, \mathrm{H}-\mathrm{C}), 13.4(\mathrm{br}$ s, OH). MS m/z: $496\left(16, \mathrm{M}^{+}+4\right), 494\left(64, \mathrm{M}^{+}+2\right), 492\left(100, \mathrm{M}^{+}\right)$, $490\left(66, \mathrm{M}^{+}-2\right), 488\left(\mathrm{M}^{+}-4\right), 447\left(70, \mathrm{M}^{+}-45\right)$. Anal. Calcd for $\mathrm{C}_{9} \mathrm{H}_{4} \mathrm{Br}_{4} \mathrm{~N}_{2} \mathrm{O}_{2}$ (491.76): C, 21.98; $\mathrm{H}, 0.82 ; \mathrm{N}, 5.70$. Found: C, 22.15; H, 0.95; N, 5.51.

\subsubsection{3. (4,5,6,7-Tetraiodo-1H-benzimidazol-1-yl)-acetic acid (21)}

Similarly to $\mathbf{2 0}$ starting from $\mathbf{1 9}$, however stirred at $50{ }^{\circ} \mathrm{C}$ : $(\mathrm{mp}$ 250-252 ${ }^{\circ} \mathrm{C}$ (decomp. with gas evol.), 70\%). UV (MeOH): 238 
(32,400), 279 (9100), 298 (8400). ${ }^{1} \mathrm{H}$ NMR $\left(\mathrm{Me}_{2} \mathrm{SO}-d_{6}\right) \delta$ (ppm): $5.21\left(\mathrm{~s}, \mathrm{H}_{2} \mathrm{C}\right.$ ), 8.37 (s, H-C), 13.3 (br s, OH). TOF MS ES ${ }^{+}: 680.6526$ $\left(\mathrm{M}^{+}+\mathrm{H}^{+}, 680.6530\right)$ Anal. Calcd for $\mathrm{C}_{9} \mathrm{H}_{4} \mathrm{I}_{4} \mathrm{~N}_{2} \mathrm{O}_{2}$ (679.76): C, 15.90; H, 0.59; N, 4.12. Found: C, 15.91; H, 0.58; N, 4.09.

\subsubsection{2 -(4,5,6,7-Tetrabromo-1H-benzimidazol-1-yl)- acetamide (22)}

Method A: The suspension of $19(260 \mathrm{mg}, 0.5 \mathrm{mmol})$ in methanolic ammonia $\left(10 \mathrm{~mL}\right.$, saturated at $0{ }^{\circ} \mathrm{C}$, diluted with $10 \mathrm{~mL}$ $\mathrm{MeOH}$ ) was stirred at room temperature for one week. The precipitate was filtered off and crystallized from DMF/dioxane gave white powder (195 mg, 80\%). $\mathrm{Mp}>325^{\circ} \mathrm{C}$.

Method B: To the stirred and refluxed mixture of TBI $(260 \mathrm{mg}$, $0.5 \mathrm{mmol})$, anhyd $\mathrm{K}_{2} \mathrm{CO}_{3}(600 \mathrm{mg})$ in dioxane iodoacetamide $(130 \mathrm{mg}, 0.7 \mathrm{mmol}$ ) was added. The stirring and reflux was continued for $2 \mathrm{~h}$. The mixture was chilled and water $(20 \mathrm{~mL})$ was added. The precipitate was filtered off and crystallized from DMF/dioxane gave white powder $(180 \mathrm{mg}, 73 \%)$. Mp $>325{ }^{\circ} \mathrm{C}$. UV $(\mathrm{MeOH}): 230$ (30,100), 267 (10,800), 273 (10,400), 302 (3500). ${ }^{1} \mathrm{H}$ NMR $\left(\mathrm{Me}_{2} \mathrm{SO}-\mathrm{d}_{6}\right) \delta(\mathrm{ppm}):\left(\mathrm{s}, \mathrm{H}_{2} \mathrm{C}\right), 7.37$ and $7.72\left(2 \mathrm{~s}, \mathrm{H}_{2} \mathrm{~N}\right), 8.43(\mathrm{~s}$, HC). MS m/z: 495 (6), $493\left(22, \mathrm{M}^{+}+4\right), 491\left(36, \mathrm{M}^{+}+2\right), 489(26$, $\left.\mathrm{M}^{+}-2\right), 487$ (7, $\left.\mathrm{M}^{+}-4\right), 447$ (65, $\left.\mathrm{M}^{+}-44\right), 410$ (100, $\left.\mathrm{M}^{+}-81\right)$. Anal. Calcd for $\mathrm{C}_{9} \mathrm{H}_{5} \mathrm{Br}_{4} \mathrm{~N}_{3} \mathrm{O}$ (490.78): C, 22.03; $\mathrm{H}, 1.03 ; \mathrm{N}, 8.58$. Found: C, 21.88; H, 1.12; N, 8.43.

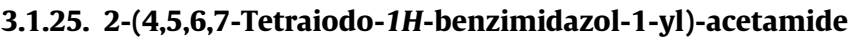
(23)

Similarly to 22 (method B) starting from 19: (mp 291-301 ${ }^{\circ} \mathrm{C}$ (decomp. with $\mathrm{I}_{2}$ evol.), 65\%). UV (MeOH): 236 (29,100), 278 (8100) 300 (8400). ${ }^{1} \mathrm{H}$ NMR $\left(\mathrm{Me}_{2} \mathrm{SO}-d_{6}\right) \delta$ (ppm): $5.05\left(\mathrm{~s}, \mathrm{H}_{2} \mathrm{C}\right)$, 7.34 and $7.68\left(2 \mathrm{~s}, \mathrm{H}_{2} \mathrm{~N}\right), 8.29(\mathrm{~s}, \mathrm{H}-\mathrm{C})$. MS m/z: $679\left(9, \mathrm{M}^{+}\right), 622$ (48, $\left.\mathrm{M}^{+}-57\right), 553$ (49, $\left.\mathrm{M}^{+}-126\right), 496$ (100, $\left.\mathrm{M}^{+}-183\right)$. Anal. Calcd for $\mathrm{C}_{9} \mathrm{H}_{5} \mathrm{I}_{4} \mathrm{~N}_{3} \mathrm{O}$ (678.78): C, 15.93; $\mathrm{H}, 0.74 ; \mathrm{N}, 6.19$. Found: C, 15.99; H, 0.77; N, 6.13 .

\subsubsection{6. $N$-Methyl-2-(4,5,6,7-tetrabromo-1H-benzimidazol-1-yl)- acetamide (24)}

The suspension of $\mathbf{1 8}$ (260 mg, $0.5 \mathrm{mmol})$ in ethanolic methylamine ( $25 \mathrm{~mL}, 20 \%$ ) was stirred at room temperature for $2 \mathrm{~d}$. The precipitate was filtered off and crystallized from dioxane gave pure white crystalline powder (230 mg, 91\%); mp 322-325 ${ }^{\circ} \mathrm{C}$ (with dec.). UV (MeOH): 232 (27,900), 267 (10,800), 273 (10,600), 302 (3600). ${ }^{1} \mathrm{H} \mathrm{NMR}\left(\mathrm{Me}_{2} \mathrm{SO}-d_{6}\right) \delta$ (ppm): 2.63 (d, $\left.3 \mathrm{H}, \mathrm{H}_{3} \mathrm{C}, J=4.6 \mathrm{~Hz}\right)$, $5.16\left(\mathrm{~s}, 2 \mathrm{H}, \mathrm{H}_{2} \mathrm{C}\right), 8.12$ (q, $\left.1 \mathrm{H}, \mathrm{H}-\mathrm{N}, J=4.7 \mathrm{~Hz}\right), 8.43$ (s, 1H, H-C). MS m/z: $507\left(9, \mathrm{M}^{+}+2\right), 505\left(13, \mathrm{M}^{+}\right), 503\left(10, \mathrm{M}^{+}-2\right), 426(100$, $\mathrm{M}^{+}$-79). Anal. Calcd for $\mathrm{C}_{10} \mathrm{H}_{7} \mathrm{Br}_{4} \mathrm{~N}_{3} \mathrm{O}$ (504.80): C, 23.79; $\mathrm{H}, 1.40$; N, 8.32. Found: C, 23.64; H, 1.52; N, 8.29.

\subsubsection{7. $N$-Methyl-2-(4,5,6,7-tetraiodo-1H-benzimidazol-1-yl)- acetamide (25)}

Similarly to described for $\mathbf{2 3}$ however stirred for $3 \mathrm{~d}$ : (mp 302$304{ }^{\circ} \mathrm{C}$ (decomp. with $\mathrm{I}_{2}$ evol.) 83\%). UV (MeOH): 237 (29,400), 278 (8200), 299 (7500). ${ }^{1} \mathrm{H}$ NMR ( $\left.\mathrm{Me}_{2} \mathrm{SO}-d_{6}\right) \delta$ (ppm): 3.29 (d, 3H, $\mathrm{H}_{3} \mathrm{C}$, $J=4.6 \mathrm{~Hz}$ ), $5.05\left(\mathrm{~s}, 2 \mathrm{H}, \mathrm{H}_{2} \mathrm{C}\right), 8.06(\mathrm{q}, 1 \mathrm{H}, \mathrm{H}-\mathrm{N}, J=4.7 \mathrm{~Hz}), 8.28$ (s, $1 \mathrm{H}, \mathrm{H}-\mathrm{C})$. MS m/z: $693\left(31, \mathrm{M}^{+}\right), 566\left(100, \mathrm{M}^{+}-127\right), 439$ (41, $\mathrm{M}^{+}$-254). Anal. Calcd for $\mathrm{C}_{10} \mathrm{H}_{7} \mathrm{I}_{4} \mathrm{~N}_{3} \mathrm{O}$ (692.80): C, 17, 34; H, 1.02; N, 6.07. Found: C, 17.30; H, 0.99; N, 6.01.

\subsubsection{8. (4,5,6,7-Tetrabromo-1H-benzimidazol-1-yl)-acetic acid hydrazide (26)}

The mixture of $\mathbf{1 8}(320 \mathrm{mg}, 0.6 \mathrm{mmol})$ and hydrazine hydrate $(500 \mathrm{mg}, 10 \mathrm{mmol})$ in ethanol $(15 \mathrm{~mL})$ was stirred and refluxed for $2 \mathrm{~h}$. The mixture was chilled and left for the crystallization. The white chromatographically pure precipitate was obtained
(220 mg, 72\%). A sample for analysis was crystallized from dioxane. $\mathrm{Mp}>305^{\circ} \mathrm{C}$ (decomp.). UV (MeOH): 232 (30,600), 267 (11,800), 273 (11,600), 302 (3800). ${ }^{1} \mathrm{H}$ NMR $\left(\mathrm{Me}_{2} \mathrm{SO}-d_{6}\right) \delta$ (ppm): 4.29 (br s, $\left.\mathrm{H}_{2} \mathrm{~N}\right), 5.50\left(\mathrm{~s}, \mathrm{H}_{2} \mathrm{C}\right), 8.44(\mathrm{~s}, \mathrm{H}-\mathrm{N}), 9.37$ (s, H-C). MS m/z: $510\left(12, \mathrm{M}^{+}+4\right), 508\left(46, \mathrm{M}^{+}+2\right), 506\left(71, \mathrm{M}^{+}\right), 504\left(47, \mathrm{M}^{+}-2\right)$, $502\left(12, \mathrm{M}^{+}-4\right), 425\left(100, \mathrm{M}^{+}-126\right)$. Anal. Calcd for $\mathrm{C}_{9} \mathrm{H}_{6} \mathrm{Br}_{4} \mathrm{~N}_{4} \mathrm{O}$ (505.79): C, 21.37; H, 1.20; N, 11.08. Found: C, 21.44; H, 1.30; N, 11.26.

\subsubsection{9. (4,5,6,7-Tetraiodo-1H-benzimidazol-1-yl)-acetic acid hydrazide (27)}

Similarly to 26, however instead ethanol methoxyethanol at $100{ }^{\circ} \mathrm{C}$ (bath temp) was used. Mp 264-266 (decomp. with gas evol.), 75\%. A sample for analysis was crystallized from dioxane/ ethanol. UV (MeOH): 236 (40,100), 282 (10,500), 299 (10,300). ${ }^{1} \mathrm{H}$ NMR $\left(\mathrm{Me}_{2} \mathrm{SO}-d_{6}\right) \delta(\mathrm{ppm}): 4.23\left(\mathrm{br} \mathrm{s}, 2 \mathrm{H}, \mathrm{H}_{2} \mathrm{~N}\right), 5.05(\mathrm{~s}, 2 \mathrm{H}$, $\left.\mathrm{H}_{2} \mathrm{C}\right), 8.27(\mathrm{~s}, 1 \mathrm{H}, \mathrm{H}-\mathrm{N}), 9.31(\mathrm{~s}, 1 \mathrm{H}, \mathrm{H}-\mathrm{C})$. MS m/z: $694\left(7, \mathrm{M}^{+}\right)$, 621 (100, $\left.\mathrm{M}^{+}-73\right), 496\left(87, \mathrm{M}^{+}-198\right)$. Anal. Calcd for $\mathrm{C}_{9} \mathrm{H}_{6} \mathrm{I}_{4} \mathrm{~N}_{4} \mathrm{O}$ (693.79): C, 15.58; H, 0.87; N, 8.08. Found: C, 15.55; H, 0.89, 8.05 .

\section{Biological evaluation}

\subsection{Materials}

\subsubsection{Phosphorylation}

CK2 activity was tested in a final volume of $25 \mu$ l containing $50 \mathrm{mM}$ Tris- $\mathrm{HCl}$ pH 7.5, $100 \mathrm{mM} \mathrm{NaCl}, 12 \mathrm{mM} \mathrm{MgCl} 2,100 \mu \mathrm{M}$ synthetic peptide substrate RRRADDSDDDDD and $0.02 \mathrm{mM}\left[\gamma-{ }^{33} \mathrm{P}-\right.$ ATP] (500-1000 cpm/pmol), unless otherwise indicated, and incubated for $10 \mathrm{~min}$ at $37^{\circ} \mathrm{C}$. Native CK2 purified from rat liver $(0.5-$ $1 \mathrm{pmol}$ ) was usually the phosphorylating enzyme. Assays were stopped by addition of $5 \mu \mathrm{l}$ of $0.5 \mathrm{M}$ orthophosphoric acid before spotting aliquots onto phosphocellulose filters. Filters were washed in $75 \mathrm{mM}$ phosphoric acid (5-10 mL/each) four times then once in methanol and dried before counting. Inhibition constants were determined from Lineweaver-Burk double-reciprocal plots of data obtained in experiments run at fixed concentration of peptide substrate and at increasing concentrations of ATP either in the absence or in the presence of variable concentrations of inhibitor. Alternatively inhibition constants were also deduced from the $\mathrm{IC}_{50} / K_{\mathrm{i}}$ Cheng-Prusoff relationship. ${ }^{33}$

\subsubsection{Molecular modeling}

The human CK2 $\alpha$ subunit was retrieved from the PDB (code $1 \mathrm{JWH})^{31}$ and processed in order to remove the ligands and all water molecules except to the one conserved. ${ }^{13}$ Hydrogen atoms were added to the protein structure using standard geometries with the MOE program. ${ }^{34}$ To minimize contacts between hydrogens, the structure were subjected to Amber99 force-field minimization until the rms (root mean square) of conjugate gradient was $<0.1 \mathrm{kcal} \mathrm{mol}^{-1} \AA^{-1}(1 \AA=0.1 \mathrm{~nm})$ keeping the heavy atoms fixed at their crystallographic positions. To strictly validate the model generated and to calibrate the high-throughput docking protocol, a small database of known CK2 inhibitors was built and a set of docking runs was performed. After the calibration phase, semiflexible ligand-docking steps with three different programs, мОЕDоск, ${ }^{34}$ GLIDE, ${ }^{35}$ and GOLD, ${ }^{36}$ were performed essentially as described previously. ${ }^{37}$ Human CK2 $\alpha$ ATP-binding pocket volume was calculated starting from the apo crystal structure $1 \mathrm{JWH}$ plus one conserved water molecule; firstly a set of MOE dummy atoms defining the active site was created, secondly the volume was calculated using a water molecule probe. ${ }^{34}$ On the other hand 1a, K17 and TCI structures and volumes were calculated with Spartan 08, using a Semiempirical Quantum Mechanical Methods AM1. ${ }^{38}$ 


\section{Acknowledgments}

This work was supported by grants to L.A.P. from AIRC, European Commission (PRO-KINASERESEARCH 503467), and by the Italian Cystic Fibrosis Research Foundation (Grant FFC\#4/2007) with the contribution of 'Banca Popolare di Verona e Novara' and 'Fondazione Giorgio Zanotto'. The Molecular Modelling Section (MMS) coordinated by Professor S. Moro (Padova, Italy) is gratefully acknowledged. The authors (A.O. and Z.K.) are grateful to Foundation for the Development Diagnostics and Therapy for partial financial support.

\section{References and notes}

1. Cohen, P. Nat. Rev. Drug Disc. 2002, 1, 309

2. Hopkins, A. L.; Groom, C. R. Nat. Rev. Drug Disc. 2002, 1, 727.

3. Kéri, G.; Örfi, L.; Erős, D.; Hegymegi-Barakonyi, B.; Szántai-Kis, C.; Horváth, Z.; Wáczek, F.; Marosfalvi, J.; Szabadkai, J.; Pató, J.; Greff, Z.; Hafenbradl, D.; Daub, H.; Müller, G.; Klebl, B.; Ullrich, A. Curr. Signal Transduct. Ther. 2006, 1, 67.

4. Knight, Z. A.; Shokat, K. M. Chem. Biol. 2005, 12, 621.

5. Meggio, F.; Pinna, L. A. FASEB J. 2003, 17, 349-368.

6. Guerra, B.; Issinger, O.-G. Curr. Med. Chem. 2008, 15, 1871.

7. Singh, N. N.; Ramji, D. P. J. Mol. Med. 2008, 86, 887-897.

8. Duncan, J. S.; Litchfield, D. W. Biochim. Biophys. Acta 2008, 1784, 33.

9. Pinna, L. A. J. Cell Sci. 2002, 115, 3873.

10. Pinna, L. A. Acc. Chem. Res. 2003, 36, 378.

11. Laramas, M.; Pasquier, D.; Filhol, O.; Ringeisen, F.; Descotes, J. L.; Cochet, C. Eur J. Cancer 2007, 43, 928.

12. Kim, J. S.; Eom, J. I.; Cheong, J. W.; Choi, A. J.; Lee, J. K.; Yang, W. I.; Min, Y. H. Clin. Cancer Res. 2007, 13, 1019.

13. Battistutta, R.; Mazzorana, M.; Cendron, L.; Bortolato, A.; Sarno, S. Kazimierczuk, Z.; Zanotti, G.; Moro, S.; Pinna, L. A. ChemBioChem 2007, 8, 1804.

14. Mazzorana, M.; Pinna, L. A.; Battistutta, R. Mol. Cell. Biochem. 2008, 316, 57-62.

15. Litchfield, D. W. Biochem. J. 2003, 369, 1-15.
16. Meggio, F.; Shugar, D.; Pinna, L. A. Eur. J. Biochem. 1990, 187, 89-94.

17. Sarno, S.; Reddy, H.; Meggio, F.; Ruzzene, M.; Davies, S. P.; Donella-Deana, A.; Shugar, D.; Pinna, L. A. FEBS Lett. 2001, 496, 44.

18. Zien, P.; Duncan, J. S.; Skierski, J.; Bretner, M.; Litchfield, D. W.; Shugar, D. Biochim. Biophys. Acta 2005, 1754, 271.

19. Szyszka, R.; Grankowski, N.; Felczak, K.; Shugar, D. Biochem. Biophys. Res. Commun. 1995, 208, 418.

20. Golub, A. G.; Yakovenko, O. Ya.; Prykhod'ko, A. O.; Lukashov, S. S.; Bdzhola, V. G.; Yarmoluk, S. M. Biochim. Biophys. Acta 2008, 1784, 143.

21. Nie, Z.; Perretta, C.; Erickson, P.; Margosiak, S.; Almassy, R.; Lu, J.; Averill, A.; Yager, K. M.; Chu, S. Bioorg. Med. Chem. Lett. 2007, 17, 4191.

22. Nie, Z.; Perretta, C.; Erickson, P.; Margosiak, S.; Lu, J.; Averill, A.; Almassy, R.; Chu, S. Bioorg. Med. Chem. Lett. 2008, 18, 619.

23. Phillips, M. A. J. Chem. Soc. 1928, 2393.

24. Smith, W. T.; Steinle, E. C. J. Am. Chem. Soc. 1953, 75, 1292.

25. Büchel, K. H. Z. Naturforsch, B 1970, 25, 934.

26. Hoover, J. R. E.; Day, A. R. J. Am. Chem. Soc. 1955, 77, 4324

27. Andrzejewska, M.; Pagano, M. A.; Meggio, F.; Brunati, A. M.; Kazimierczuk, Z. Bioorg. Med. Chem. 2003, 11, 3997.

28. Pagano, M. A.; Andrzejewska, M.; Ruzzene, M.; Sarno, S.; Cesaro, L.; Bain, J.; Elliott, M.; Meggio, F.; Kazimierczuk, Z.; Pinna, L. A. J. Med. Chem. 2004, 47, 6239.

29. Mattern, D. L. J. Org. Chem. 1984, 49, 3051

30. Zien, P.; Bretner, M.; Zastapilo, K.; Szyszka, R.; Shugar, D. Biochem. Biophys. Res. Commun. 2003, 306, 129.

31. Niefind, K.; Guerra, B.; Ermakowa, I.; Issinger, O.-G. EMBO J. 2001, 20, 5320.

32. Politzer, P.; Lane, P.; Concha, M. C.; Ma, Y.; Murray, J. S. J. Mol. Model. 2007, 13, 305.

33. Burlingham, T. B.; Widlanski, T. S. J. Chem. Ed. 2003, 80, 214

34. Molecular Operating Environment (MOE 2008.10), C. C. G., 1255 University St. Suite 1600, Montreal, Quebec, Canada, H3B 3X3.

35. Schrodinger, I.; Schrodinger: Portland, OR, 2001

36. Jones, G.; Willett, P.; Glen, R. C.; Leach, A. R.; Taylor, R. J. Mol. Biol. 1997, 267. 727.

37. Cozza, G.; Bonvini, P.; Zorzi, E.; Poletto, G.; Pagano, M. A.; Sarno, S.; DonellaDeana, A.; Zagotto, G.; Rosolen, A.; Pinna, L. A.; Meggio, F.; Moro, S. J. Med. Chem. 2008, 49, 2363.

38. Wavefunction: Irvine, CA USA, 2002. 